ERC Working Papers in Economics 14/09

August/ 2014

\title{
Defining and measuring informality in the Turkish labor market
}

\author{
Elif Öznur Acar \\ Department of Banking and Finance, \\ Çankaya University, Ankara, TURKEY \\ E-mail: elifoznurkan@ cankaya.edu.tr \\ Phone: + (90) 3122331208
}

\author{
Aysit Tansel \\ Department of Economics, Middle East Technical University, \\ Ankara, TURKEY \\ Institute for the Study of Labor (IZA) Bonn, GERMANY \\ Economic Research Forum (ERF) Cairo, EGYPT \\ E-mail: atansel@ metu.edu.tr \\ Phone: + (90) 3122102073
}




\title{
DEFINING AND MEASURING INFORMALITY IN THE TURKISH LABOR MARKET*
}

\author{
Elif Öznur ACAR \\ Department of Banking and Finance \\ Cankaya University, Ankara, Turkey \\ E-mail: elifoznurkan@cankaya.edu.tr \\ Telephone: 90.312 .2331208 \\ Fax: 90.312.233 1027 \\ and \\ Aysit TANSEL \\ Department of Economics \\ Middle East Technical University, Ankara, Turkey \\ Institute for the Study of Labor (IZA) Bonn, Germany \\ Economic Research Forum (ERF) Cairo, Egypt \\ E-mail: atansel@metu.edu.tr \\ Telephone: 90.312 .2102073 \\ Fax: 90.312.210 7964
}

August 2, 2014

\begin{abstract}
:
This paper investigates how informality can be defined and measured in the Turkish labor market. Two alternative definitions of informality are used to explore their relevance and implications for the Turkish labor market using descriptive statistics. They are the enterprise definition and the social security definition. Further, contributions of individual and job characteristics to the likelihood of informality are investigated using multivariate probit analysis under the two definitions. The social security registration criterion is found to be a better measure of informality in the Turkish labor market given its ability to capture the key relationships between several individual and employment characteristics and the likelihood of informality. The study suggests that preference should be given to social security definition of labor informality for a more accurate depiction of the Turkish labor market. The suitability of the two alternative definitions of informality in the Turkish labor market and its implications have not been investigated before.
\end{abstract}

Keywords: Informality, Definition, Measurement and Likelihood, Turkey. JEL Classification: J20, J21, J24, 017.

\footnotetext{
*This paper is based on Elif Oznur Kan's PhD thesis (see Kan, 2012) prepared under the supervision of Aysit Tansel at the Department of Economics, METU. We would like to thank Hakan Ercan, Tolga Omay and Ozan Acar for helpful comments on the thesis, and to Murat Karakas, responsible of Labor Force and Living Conditions Group at the Turkish Statistical Institute for his help in implementing this study. An earlier version of this paper was presented at the workshop on "Shadow Economies: Definition, Measurement and Implications" at the Boğaziçi University, Istanbul on 12 October 2012 and at the Workshop on Economic Statistics at the Turkish Statistical Institute, September 9-10, 2013 in Ankara, Turkey. We would like to thank the participants of these workshops for their comments. Any errors are our own.
} 


\section{INTRODUCTION}

Informal employment has always been at the center of theory and policy debate in terms of its importance, determinants and policy implications. Considering high levels of prevalence and persistence of informality in developing countries it is expected to influence labor markets in many ways and for many years to come in these countries. Therefore it requires special attention and proactive approach. In order to effectively address its nature and dynamics, however, one first needs a profound understanding of the informality concept and its dimensions. Data limitations and its intrinsic heterogeneity have rendered measuring informal employment a challenge. There have been numerous attempts in the literature to identify informality. The resulting vast array of methodologies should not be seen as an obstacle but as a tool to comprehend its many different facets. Along these lines, this study proposes a definitive framework that can be used as an initial step to detailed analysis of informal employment in the Turkish labor market.

Given its economic and demographic dynamics, Turkey indeed provides rich evidence for a multifaceted informal labor market. The issue is elaborated by several authors (Tansel, 1997, 1999, 2001; Bulutay, 2000; Bulutay and Taşt1, 2004; Özdemir et al., 2004; SPO, 2009; Kenar, 2009; Reis et al., 2009; Aydin et al., 2010; OECD, 2010; World Bank, 2010; Ercan, 2011). However, existing evidence on how to define informality is scanty. Data limitations and conceptual obscurity have impeded generalizable and comparable analyses. This study elucidates the informality in the Turkish labor market in terms of its definition, measurement and salient features.

A better understanding of the definition and measurement of labor informality is of utmost importance in such a developing country context for several reasons. First, as Perry et al. (2007) argue: "The term informality means different things to different people, but almost always bad things: unprotected workers, excessive regulation, low productivity, unfair competition, evasion of the rule of law...". Second, particular vulnerable groups such as young, women and migrants are often disproportionately over represented in informal employment. Therefore, diagnosing the extent of informal employment is crucial for identifying the risks and sources of socioeconomic inequality.Third, informality is a multifaceted phenomenon which in practice refers to several types of workers and activities, ranging from informal employees of informal or formal enterprises to unpaid family workers, and from marginal own-account workers to prosperous employers. The famous informal sector elephant metaphor proposed by Hernando de Soto is based on this aspect. Thus, as Jütting et al. (2008) state, defining and comparing informal employment in multiple ways enable comprehending different dimensions of the phenomenon.

The empirical analysis consists of developing two alternative definitions of labor informality, gauging the extent of their association, and exploring the relevance and implications of each for the Turkish labor market using a number of individual and employment characteristics. The first, is an enterprisebased definition which describes informality with employment in the informal sector, where informal sector refers to small firms and self-employment. The second definition is based exclusively on social protection coverage independent of the nature of the sector one is employed. Then, informality based on these two definitions are comparatively analyzed in multiple dimensions including gender, age, education, household size, geographical region, economic sector, establishment size and employment status. The first part of the analysis is descriptive in nature and attempts to decompose the structure of labor informality in Turkey. We next estimate multivariate probit regressions of the probability of being informal on a set of individual and job attributes that are well established in the literature as potential determinants of informality.

To the best of our knowledge, this analysis is the first to compare alternative definitions and measures of informal employment in Turkey using 2006-2009 Survey of Income and Living Conditions (SILC). 
The analysis provides a synthesis of empirical and theoretical literature in the context of Turkey. Moreover, thanks to the novel nature of SILC data set, time span of this study allows exploring the existence and extent of any effect of global economic crisis in the Turkish labor market along the formal/informal divide. Thus, the ultimate objective is to improve an understanding of informality concept and stimulate vigorous analyses of the labor markets and related policy.

This paper is organized as follows. The next section reviews the literature on the definition and measurement of informal employment. Section 3 presents a comprehensive descriptive analysis of different definitions of informality. In Section 4 results of the multivariate analysis are discussed. Section 5 concludes.

\section{LITERATURE SURVEY}

The initial formal versus informal divide of economic activities and employment can be traced back to the dual economy theory, introduced by Lewis (1954), Kuznets (1955) and Harris and Todaro (1970). They explained economic development by the emergence and growth of the modern manufacturing sector through absorbing labor from the traditional agriculture sector (Bromley, 1978). Hart (1973) extended the dualist terminology by decomposing the economy into formal and informal sectors analogous to modern and traditional sectors, respectively. In this way, he first coined the term informal sector to describe self-employment and small enterprises activities of the reserve army of urban unemployed and underemployed to generate income.

The first internationally agreed definition was adopted in the $15^{\text {th }}$ International Conference of Labor Statisticians (ICLS) in 1993. Informal employment was defined as comprising of "all jobs in informal sector enterprises, or all persons who, during a given reference period, were employed in at least one informal sector enterprise" (Hussmanns, 2005). Under this definition, informality is identified based on the characteristics of the production units in which the activities took place, rather than in terms of the characteristics of the worker or the job. Hence, it is named enterprise definition of informality. This approach is the longest established in the existing theoretical and empirical literature. The unit of observation is enterprises and main measurement criterion is the number of workers in an enterprise.

The enterprise definition was later criticized for that it might fail to capture those marginal micro-scale informal activities which are often unreported by individuals, and that it cannot fully capture the increasing variety of informal employment forms (Hussmanns, 2004). Therefore, a broader informality specification relating to a job-based concept of informal employment was adopted in $17^{\text {th }}$ ICLS in 2003 (Hussmanns, 2004). In a nutshell, Chen (2007) recapitulates the new labor informality concept as comprising self-employed in informal enterprises and wage employment in informal jobs. Informal jobs refer to jobs that are not subject to national labor legislation, income taxation, social protection or entitlement to certain employment benefits. The new approach, combining both enterprise and job-type characteristics, is named the productive definition of informality.

More recently, a third strand emerged. The idea was to expand the definition of informal employment to encompass the increasing variety of informal activities and workers by transiting from an enterprise-based approach to a worker/employment-based approach. The idea was that informality should be defined in terms of legal status of employment, rather than firm or job characteristics (Henley et al., 2009). In official ILO terms, an employment relationship is considered to be informal if it is not subject to labor legislation, social protection, taxes or employment benefits (Hussmanns, 2005). In practice, the definition translated into several measurement criteria such as having a signed 
contract, belonging to a union, being entitled to benefits such as health insurance or pension, working at the public sector, or paying taxes (Saavedra and Chong, 1999). It is referred to as legalistic, contract-based or social protection definition of informality.

In Turkey, the informal sector concept was officially articulated for the first time by the Turkish Statistical Institute (TurkStat) in 1988 Household Labor Force Survey (HLFS). Size, legal and residency status of the firm were used to describe the concept (Toksöz and Özşuca, 2003). Later, TurkStat identified the informal employment in HLFS as employment without social security in the main job during the reference week (TurkStat, 2011). Using this definition informal employment was 38.4 percent as of January 2012 (TurkStat, 2012). Informality was 82.8 percent in agricultural employment and 25.8 percent for non-agricultural employment in the same year. Evidently, these figures beg a more nuanced discussion on the nature and underlying dynamics of informal employment.

Given the importance of understanding the nature of labor informality, this study endeavors to provide an extensive snapshot of its incidence in the Turkish labor market. We examine the relevance and implications of two different definitions of informality. We use the cross-sectional data of SILC for 2006, 2007, 2008 and 2009. The original cross-sectional samples consist of 30,186 individuals for 2006; 30,263 individuals for 2007; 31,121 individuals for 2008 and 32,539 individuals for 2009. We consider only those individuals who are 15-64 years of age, currently employed, and for whom information on employment status and social security registration status are available. This selection leaves 13,016, 13,458 13,956 and 14,375 individuals for 2006, 2007, 2008 and 2009 respectively. ${ }^{1}$

In the following analysis, we identify two different definitions of labor informality. They are are adopted to be consistent with the international guidelines provided by ILO, comparable with other countries' studies. Following are the two definitions considered.

Enterprise Definition: The sum of employers and employees in small firms which in the SILC data set corresponds to firms with 10 or less workers, and self-employment in the forms of either own-account workers (excluding administrative, professional and technical workers) or unpaid family workers. This definition describes informality with employment in the informal sector. Informality is identified based on the characteristics of the enterprise rather than the worker. Informality measure is constructed using the employment category and firm size questions in the SILC questionnaire.

Social Security Definition: Those workers who are not registered at the social security institute regardless of whether they work in the formal or informal sector are considered as informal workers. This definition represents the legalistic or social security approach. In the SILC survey, this corresponds to the question whether the respondent is registered to the social security or not for his main job. ${ }^{2}$

The empirical analysis consists of two parts. First, we analyze and compare these two definitions using a number of individual and employment characteristics. The analysis is descriptive in nature, with an aim decompose the structure of labor informality in Turkey. Moreover, a four year time span is adopted to trace the transformation dynamics over time, and detect any likely effect of the recent global economic crisis in the late 2008 and 2009 on the structure of Turkish labor market. Second, we

\footnotetext{
${ }^{1}$ For analyses on non-agricultural employment, the sample further reduces to 8,412 individuals for 2006; 8,774 individuals for 2007; 9,575 individuals for 2008; and 9,771 individuals for 2009.

${ }^{2}$ A third definition of informality is also considered which includes workers not covered by the social security in the informal sector and the workers not covered by the social security in the formal sector. The analysis using this definition can be found in Kan (2012).
} 
perform a multivariate probit analysis to examine the predictive power of various factors on informality.

\section{DESCRIPTIVE ANALYSIS OF LABOR INFORMALITY}

In this section, we present a preliminary characterization of the Turkish labor market over the fouryear period 2006-2009, with a particular focus on informal employment based on the two definitions of informality described in the previous section. We first assess the extent to which informality prevails and varies across the two definitions and time periods, and then in the next section examine its nature using individual socio-demographic, household and employment attributes.

Table 1 reports the sample proportions of workers classified as informal under the two definitions over the four years. We conduct the analysis for total and non-agricultural employments separately in order to detach the likely effects of highly informal agriculture sector on the dynamics of labor informality. We observe that share of informal employment in total employment is higher under the enterprise definition than under the social security definition. Specifically, informality rate is 57 percent under the enterprise definition and 46 percent under the social security definition in 2009. The similar figures for the non-agricultural sector are 10-15 percentage points lower namely, 44 and 32 percent respectively. This confirms that the agriculture is a highly informal sector by its nature, hence exacerbates the overall informality figures. We also observe that the informality rates based on the enterprise definition remain stable over 2006-2009 period, whereas informality rates based on the social security definition exhibit a discernible decreasing trend over this period.

\section{<Insert Table 1 here>}

When sample is divided by gender, similar results apply except for the fact that female workers demonstrate a remarkably higher level of informality regardless of the definition used in the total sample but not in the non-agricultural sample. For males there is a decline in the informality rate over the period which reverses itself in 2009. This may be due to the impact of the 2008-2009 global economic crisis on the Turkish labor market. ${ }^{3}$ It is also interesting that the enterprise and social security definitions overlap to a remarkable extent when female workers are considered.

A breakdown of informality by age is given in Table 2 . We first note the U-shaped relationship between informality and age. That is, the share of those who are informally employed is higher for the young and the elderly compared to the middle-aged workers. For the 15-24 age-group, informality is lowest under the enterprise definition possibly due to the inexperience of this age group. Informality rate increases for this age group in 2009 unlike the other age groups. Thus young are affected more by the global crisis compared to the middle-aged workers. Confirming the mainstream literature social security coverage reaches its highest level for the middle aged workers. Informality rate increases dramatically for the 45-54 and 55-64 age-groups under both definitions. This finding could be the result of generous pension schemes causing an epidemic of early retirement, after which elder individuals often move into informal types of employment. ${ }^{4}$ Almost identical patterns are observed in

\footnotetext{
${ }^{3}$ For a comprehensive analysis of the impact of global crisis on Turkish employment, see Ercan (2010).

${ }^{4}$ Until 1992, Turkish pension system stipulated a minimum retirement age threshold of 60 for males and 55 for females, and a minimum premium payment equivalent to 5000 days of work. Law No.3774, which was passed in February 1992, pledged a minimum period of social security system attachment for 25 years for males and 20 for females (World Bank, 2006). In 1999, the minimum age thresholds were reinstated at 60 for male and 58 for female, and minimum premium payment requirement was increased to 7000 days of work. With the latest reforms which came into force in October 2008, benefit entitlements and incentives for early retirement were reduced to a large extent. In particular, retirement age is increased from 60 and 58 for men and women, respectively, to 65 for both, and the number of minimum
} 
the non-agricultural sample albeit with lower levels of informality for all age groups.

\section{$<$ Insert Table 2 here>}

Table 5 shows that informality is strongly associated with education level according to the both definitions. Informality rate is over 90 percent for the illiterates according to the both definitions but falls progressively as educational attainment increases. This evidence is consistent with the basic premise that informality as mostly a low-skill phenomenon.

\section{$<$ Insert Table 3 here>}

When we examine the non-agricultural sample the informality falls for the illiterates by about 30 percentage points in the enterprise definition. This reflects the weightiness of the unpaid family workers among the illiterates in agriculture sector. Unpaid family workers seem to suffer significantly from informality. We note that the informality is lower among the vocational high school graduates. Also noteworthy is the finding that informality rate over time remains about the same when workers with high school or above education are considered. However, the informality rate among primary and secondary school graduates increase by around 4 percent in 2009. This implies that global economic crisis affected mostly the primary and secondary school graduates.

Table 6 details the informality rate by employment status. Regular employees are by far the least informal under both definitions compared to all other groups. It is interesting to note that the proportion of regular employees without social security registration has declined to 17 percent in 2009. The two definitions substantially overlap for the regular employees especially for the nonagricultural sample implying that regular employees are only rarely or never employed in agriculture. The most salient characteristic of the casual employees is that they are employed without social security. This rate is higher than the rate under enterprise definition. This group is severely affected by the global crisis since informality for them increases significantly during the global crisis year of 2009. Results do not change much for the non-agricultural sample.

\section{$<$ Insert Table 6 here >}

Turning to employers, one first notes that they are almost exclusively informal at around 90 percent under the enterprise definition but only between 25 to 38 percent of the employers do not have social security coverage. Under the enterprise definition employers are classified as informal if working in a firm with 10 or less workers. This suggests that most employers are associated with small-scale operations in the Turkish economy although their self-registration at the social security institute is quite high and increasing over time. ${ }^{5}$ The conclusions for the non-agricultural sample are almost identical to that of entire sample, suggesting that employers operate mostly in the non-agricultural sector. As for the self-employed, informality is lower under the social security definition than under the enterprise definition, and furthermore informality is lower in the non-agricultural sample.

contribution days are increased from 7000 to 7200 (OECD, 2009). However, these stipulations will be phased in gradually and become effective for age cohorts born after 1980.

\footnotetext{
${ }^{5}$ The government of Turkey has been pursuing a combat against informality since the opening of accession negotiations with European Union in October 2005. In particular, a comprehensive action plan "The Struggle Against Informal Employment" (KADİM) has been launched under the aegis of Ministry of Labor and Social Security. The project was initially focused on informal employment of illegal foreign employees (Ben Salem et al., 2011). More recently, the Government has incorporated fight against informality strategy as a separate section into its Annual Programs. A broader program, namely "Struggle Against the Informal Economy Action Plan", was out into action under the leadership of Revenue Administration among various other institutions in 2009. The comprehensive and resolute plan identifies three main targets (i) promoting formal activities; (ii) strengthening audit capacity and increasing the deterrence of sanctions; (iii) establishing and strengthening institutional and societal consensus (World Bank, 2010).
} 
Regarding the unpaid family workers, we note that they are almost exclusively employed as informal and in agriculture sector. In addition, the two definitions substantially overlap indicating that regardless of the definition is used, unpaid family work is an informal phenomenon.

Table 5 depicts informality by sector of economic activity. Agricultural employment turns out to be entirely informal under both definitions with only about 10 percent of the workers being formal. On the other hand, the share of informal work is considerably low in mining, utilities, finances, public administration, education and health sectors and the informality rates under the two definitions are similar. Further, most of these sectors like education and health are operated by the state although SILC does not have information on whether the firms are public or private and some are large-scale enterprises like mining. Manufacturing and business services sectors display lower informality than the average level. Moreover, in these sectors social security registration increases by 10 percentage points from 2006 to 2009, implying that they are not affected by the global crisis. Construction has the second highest informality rate after agriculture. In this sector, social security based informal employment rate decreases over time but the enterprise based definition is higher and does not change over time.

< Insert Table 5 here>

Regarding the relationship between economic crisis and informal employment, common assumption postulates that informal employment does expand during an economic crisis as workers who lose jobs in the formal sector are often displaced in informal sector. However, Ercan (2010) shows that this was not the case in the recent global crisis in Turkey since job losses were larger in the informal sector during this period. The figures in Table 5 based on social security coverage confirms this argument since informality rate increased in sectors like mining and transportation in 2009.

\section{MULTIVARIATE ANALYSIS OF LABOR INFORMALITY}

The marginal effects of the probit estimation results for the enterprise definition are reported in Table 6 . They show the impact of explanatory variables on the probability of being informal. Being female is not statistically significant implying that the enterprise definition is unable to capture the wellestablished association between gender and informality. The slightly significant coefficient for 2009 indicates that women are more likely than men to be informal. This may be an implication of the economic crisis in 2009. Ercan (2010) reports an increase in the women's informal self-employment during the crisis which may be due to the "added worker effect" when women step into the labor market to substitute for their husbands who lost jobs.

\section{< Insert Table 6 here>}

Regarding age, the workers aged 25-44 and 45-64 are both significantly less likely to be informal under the enterprise definition compared to the reference category of aged 15-24 confirming the wellknown stylized fact that young and less experienced workers are more prone to working informally as they lack experience often suffer from barriers to entry into formal employment. In 2009, the sign of the middle age dummy becomes significantly positive, whereas older age dummy ceases to be statistically significant. This finding can be interpreted as middle age workers being affected disproportionately higher than the young during the crisis. This may be due to higher job losses in formal sector for middle age workers who may find re-employment in informal sector in case of a layoff, whereas young workers may either become unemployed or move out of labor force. 
Turning to education, we find that the coefficient estimates contradict the basic premises of the established theory on the association between schooling and being informal. More specifically, workers with any higher level of educational attainment have significantly higher probability of being informal compared to the reference category of primary school graduates. This evidence pinpoints to another drawback of enterprise definition that is failing to identify one of the most prominent stylized facts related to informality.

Household demographic structure seems to play almost no role in explaining informal employment. The effects of being married and/or being a household head are positive but not statistically significant. The only exception is the statistically significant married dummy for 2009 , which implies that married individuals became more likely to be informal in the aftermath of the crisis. Whereas having children in the household exhibits a negative relationship with being informal, albeit only marginally significant in 2008. As a result we can say that enterprise definition fails to notice any potential influence of household characteristics on the likelihood of being informal.

Sector of economic activity plays somewhat a fair role in explaining the probability of being informal, though seems to overlook some of the well-established premises. Compared to the base category of manufacturing workers, workers in trade, hotels and restaurants, finances, health and other services sectors are found to display a significantly lower probability of being informal as expected, although the explanatory power decreases to a notable extent for the year 2009. In contrast, the prominent relationships of informality with agriculture and construction activities are not captured under the enterprise definition of informality.

Occupation emerges as the most significant and powerful determinant of the probability of being informal. In particular, workers in all occupations other than legislators and technicians display a significantly higher probability of being informal when compared to the reference group of professional workers. However, we prefer to approach this evidence with skepticism, since the enterprise definition by construction employs occupational criteria when classifying workers as formal and/or informal. In particular, it excludes self-employment in the forms administrative, professional and technical work from informal employment. Therefore, results should be viewed only as a statistical outcome without attaching a qualitative meaning. Similar findings and interpretations may also apply to the firm size variable. It is also used as an explicit criterion in the enterprise definition. The base category is the small firms which employ 10 or less workers. The medium sized firms employ 11-49 workers and the large firms employ 50 or more workers. The results with regards to the firm size are ambiguous. Thus, we prefer not to treat them as meaningful for this particular case. Overall, enterprise definition falls short of explaining the well-established association between informality and factors such as occupation and firm size, since that it rather uses these relationships as measurement criteria in its very definition.

The location is defined as urban if the population is over 20,000 and rural otherwise. We find that the workers in urban areas are significantly more likely to be informal between 2006 and 2008 than the workers in rural locations and the coefficient of urban dummy ceases to be significant in 2009 . According to TurkStat, agricultural employment increased during the recent crisis. Ercan (2010) argues that urban informal job holders are the ones who were affected most during the crisis and when the individuals or families lost their jobs in the urban areas they returned to their villages in the rural areas, and started to work as unpaid family workers. This argument clearly explains the coefficient of urban dummy loosing its statistical significance in 2009, as rural informality have indeed expanded considerably in the aftermath of the economic crisis

We next discuss marginal effects of the probit estimation results for the social security definition reported in Table 7. Gender now emerges as a powerful and robust predictor of the likelihood of being 
informal. In particular, women are approximately 40-50 percentage points more likely than men to work informally given equal qualifications ceteris paribus. This may be due to involuntary or voluntary factors. First, women often face higher entry barriers into formal work opportunities. They might also voluntarily opt out of formal employment which is often subject to stricter working conditions and regulations, given their reproductive role and traditional gender division of labor in the Turkish family structure. Therefore we can argue that social security definition is superior compared to the enterprise definition since it can properly capture the gender dimension of informality. < Insert Table 10 here>

Regarding age, we first note that workers aged 25-44 exhibit a significantly lower likelihood of being informal than the reference group of workers aged 15-24 This evidence is robust over time, and indeed conforms to the mainstream literature which associates informality with young and inexperienced workers. However, for the workers of aged 45-64 the marginal effect is statistically insignificant implying that the young and the old are equally likely to be informal.

As for the education the results reveal a strong schooling pattern. In particular, compared to the base category of primary school graduates those with higher schooling exhibit a significantly lower probability of being informal, whereas those who are illiterate or have no degree have approximately 50 percentage points higher probability of working informally in all years confirming the expected patterns. Thus, social security definition gives the expected results with regards to education also.

The household characteristics variables now statistically significant. The effect of marriage on probability of being informal is significant implying that married workers are approximately 20 percentage points less likely to be informal compared to those who are single. This might reflect that married individuals are less willing to take risks associated with informal employment, and prefer safer employment in formal sector. Due to similar reasons, being a household head statistically significantly reduces the likelihood of informal employment, around 20 percentage points. The results suggest that individuals in households with children posit a higher likelihood of informality. The increased financial burden of children may make individuals more likely to consent with informal jobs. Thus, the expected evidence on household variables, are well captured under the social security definition.

Informal status defined on the basis of social security registration displays an almost completely different relationship with sectors of economic activity, compared to that of based on the enterprise definition. Agriculture emerges as a strong predictor of being informal under social security definition throughout the period. This is consistent with the mainstream literature where informality has been viewed as mostly an agricultural phenomenon which is also salient in the Turkish labor market. Similarly, construction workers are now 70-80 percentage points more likely to be informal compared to their counterparts in manufacturing for all years. This finding, albeit was unidentified by the enterprise definition. The construction workers are mostly casual day-laborers and account for a major fraction of informal employment.

Regarding the firm size, those workers who are not registered with social security are significantly more likely to be employed in small firms. The workers in the medium sized firms have 70-80 percentage point lower likelihood of being informal and those in the large firms have almost 150 percent lower likelihood of being informal. We now observe a negative and statistically significant relationship between probability of being informal and living in urban areas for 2008 and 2009. As a result, we can conclude that the social security definition better captures the stylized fact of lower informality in urban areas in Turkey. 


\section{CONCLUDING REMARKS}

In this paper, we consider how informality can be defined and measured in the Turkish labor market given that there is no single universally accepted definition, but several definitions tailored to different time and space contexts. In this endeavor, we construct two alternative definitions following theoretical and empirical literature. Enterprise definition corresponds to employment in the informal sector, which associates informality with activities of small-scale enterprises and self-employed; Social security definition represents the legalistic view which identifies informality with lack of social security. The first part of the paper is descriptive in nature, attempts to determine the degree of congruence between the two alternative definitions and decompose the structure of labor informality in Turkey. Next, a multivariate analysis is conducted to explain the likelihood of informality using various personal and job attributes as explanatory variables.

Overall, informal employment accounts for about 57 percent of the total sample when enterprise definition is used and about 46 percent of the total sample when social security definition is used in 2009. For the non-agricultural sample, both figures fall by around 10 percentage points. Regarding variation over time, the enterprise definition remains about the same over time whereas social security definition declines over time from 2006 to 2009. Females are significantly more informal than males under both definitions, and overlap between the two definitions is higher for females. Moreover, we observe a U-shaped relationship between informality and age which is commonly postulated in the mainstream literature. Further, in conformity with the conventional wisdom, informality declines as educational attainment increases regardless of the definition used. A breakdown of informality by sector of economic activity and occupation also marks several evident patterns.

The probit analysis provides a more profound characterization of informal employment in the Turkish labor market. The results, overall, point towards social security based informality definition being superior over enterprise definition in capturing the association between key individual and job characteristics and informality. Specifically, gender, age, education, household demographics, sector of economic activity and firm size variables all confirm the well-established stylized facts when we use social security definition. Whereas, enterprise definition falls short of properly detecting renowned basic premises even in some cases not detecting them at all.

To conclude, this study provides a comprehensive and detailed diagnosis of the Turkish labor market. We find that social security registration criterion is a better measure of informality than the enterprise definition in the Turkish labor market given its ability to capture key relationships between several individual and employment characteristics and the likelihood of informality. Moreover, social security definition appears as the most responsive measure with regards to time and impacts of crisis. Along these lines, we recommend researchers and policy-makers prefer the social security to define labor informality for more accurate analyses of the Turkish labor market. 


\section{REFERENCES}

Aydın, E., M. Hisarciklilar, and İ. İlkkaracan (2010). "Formal versus Informal Labor Market Segmentation in Turkey in the course of Market Liberalization", Topics in Middle Eastern and North African Economies, 12, 1-43.

Ben Salem, M., I. Bensidoun and S. Pelek (2011). "Informal Employment in Turkey: an overview", Région et Développement, 34, 58-84.

Bosch, M. and W. Maloney (2005). "Labor Market Dynamics in Developing Countries: Comparative Analysis Using Continuous Time Markov Processes", Policy Research Working Paper Series 3583, The World Bank.

Bromley, R. (1978). "The urban informal sector: why is it worth discussing?", World Development, 6 (9-10), 1033-1039.

Bulutay, T. (2000). The Unrecorded Economy as Related to the Labour Market, Ankara: State Institute of Statistics.

Bulutay, T. and E. Taştı (2004). "Informal Sector in the Turkish Labour Market", Working Papers 2004/22, Turkish Economic Association.

Chen, M. A. (2007). "Rethinking the Informal Economy: Linkages with the Formal Economy and the Formal Regulatory Environment”, DESA Working Papers 46, Department of Economic and Social Affairs, United Nations.

De Soto, H. (1990). The Other Path: The Invisible Revolution in the Third World, New York: Harper Trade.

Ercan, H. (2010). "The Impact of the Global Financial Crisis on Employment In Turkey", In Crisis and Turkey: Impact Analysis of Crisis Response Measures, Ankara: International Labour Organization Office For Turkey.

Ercan, H. (2011). “Occupational Outlook in Turkey”, Ankara: International Labour Organization Office For Turkey.

Harris, J.R. and M.P. Todaro (1970). "Migration, Unemployment and Development: A Two-Sector Analysis", The American Economic Review, 60 (1), 126-142.

Hart, K. (1973). "Informal Income Opportunities and Urban Employment in Ghana", The Journal of Modern African Studies, 11 (1), 61-89.

Henley, A., G.R. Arabsheibani and F.G. Carneiro (2009). "On defining and measuring the informal sector: Evidence from Brazil”, World Development, 37 (5), 992-1003.

Hussmanns, R. (2004). Defining and measuring informal employment, Geneva: International Labour Office.

Hussmanns, R. (2005). "Measuring the informal economy: From employment in the informal sector to informal employment", Working paper 53, International Labour Organization.

Jütting, J., J. Parlevliet, and T. Xenogiani (2008). "Informal employment re-loaded". OECD 
Development Centre Working Papers 266, Organisation for Economic Co-operation and Development (OECD).

Kan, E. O. (2011), "Essays on Informal Sector in the Turkish Labor Market", Unpublished PhD Thesis, Middle East Technical University, Ankara

Kanbur, R. (2009). “Conceptualizing Informality: Regulation and Enforcement”, IZA Discussion Papers 4186, Institute for the Study of Labor (IZA).

Kenar, N. (2009). "Informality: Regulations, Institutions and Enforcement”, Background paper for the World Bank Country Economic Memorandum (CEM)- Informality: Causes, Consequences, Policies.

Kuznets, S. (1955). "Economic Growth and Income Inequality", American Economic Review, 45, 128.

Levent, H., E. Taştı and D. Sezer (2004). “Isgucü Piyasasının Katmanlı Yapısı”, Türkiye'de İsgü̈cü Piyasasının Kurumsal Yapısı ve Işsizlik, 27-63, Istanbul: TÜSİAD.

Lewis, W.A. (1954). "Economic Development with Unlimited Supplies of Labor", Manchester School of Economic and Social Studies, 22, 139-191.

Loayza, N., L. Serven and N. Sugawara (2009). "Informality in Latin America and the Caribbean", Policy Research Working Paper Series 4888, The World Bank.

Maloney, W. (1999). "Does Informality Imply Segmentation in Urban Labor Markets? Evidence from Sectoral Transitions in Mexico", World Bank Economic Review, 13 (2), 275-302.

Maloney, W. (2004). “Informality Revisited”, World Development, 32(7), 1159-1178.

OECD (2008). "Declaring Work or Staying Underground: Informal Employment in Seven OECD Countries", OECD Employment Outlook, 79-137, Paris: Organisation for Economic Co-operation and Development.

OECD (2009). "IOPS Country Profiles: Turkey, Country Pension Design”, OECD Global Pension Statistics, Paris: Organisation for Economic Co-operation and Development.

OECD (2010). OECD Economics Surveys: Turkey 2010, Paris: Organisation for Economic Cooperation and Development.

Özdemir, A. M., D. Erel and G. Yücesan-Özdemir (2004). "Rethinking Informal Labour Market in Turkey: A Possible Politics for Unions”, South East Europe Review, 7 (2), 33-42.

Packard, T. (2007). "Do Workers in Chile Choose Informal Employment? A Dynamic Analysis of Sector Choice", Policy Research Working Paper Series 4232, The World Bank.

Perry, G., W. Maloney, O. Arias, P. Fajnzylber, A. Mason and J. Saavedra (2007). Informality: Exit and Exclusion, World Bank Latin America and Caribbean Studies, Washington, D.C.: The World Bank.

Saavedra, J. and A. Chong (1999). "Structural reform, institutions, and earnings: evidence from the formal and informal sectors in urban Peru", The Journal of Development Studies, 35 (4), 95-116. 
State Planning Organization (SPO) (2009). Action Plan of The Strategy For Fight Against Informal Economy, Ankara: State Planning Institute.

Tansel, A. (1997). “Informal Sector Earnings Determination in Turkey”, ERF Regional Trade, Finance and Labor Markets in Transition Conference Proceedings, September 7-9, 153-161, Economic Research Forum.

Tansel, A. (1999). "Formal versus Informal Sector Choice of Wage Earners and Their Wages in Turkey", ERF Working Papers 9927, Economic Research Forum.

Tansel, A. (2001). "Wage Earners, Self Employed and Gender in the Informal Sector in Turkey", ERF Working Papers 0102, Economic Research Forum.

Togan, S. (2001). "İşü̈cü Piyasasında Kayıtlı ve Kayıtdışı Sektörler”, in T. Bulutay (Ed.), İşgücü Piyasası Açısından Kayıtdışı Ekonomi, Ankara: Turkish Statistical Institute.

Toksöz, G. and S. Özşuca (2003). Sosyal Koruma Yoksunlugu: Enformel Sektor ve Kucuk Isletmeler, Ankara: Ankara Universitesi SBF Yayinlari.

Tunalı, İ. (2000), "Basic Conceptual Problems in Analyses of the Informal Sector," in T. Bulutay (Ed.), Informal Sector I, Ankara: Turkish Statistical Instutite.

Tunal1, İ. and H. Ercan (1998). "Labor Market Segmentation in Turkey”, in T. Bulutay (Ed.), Main Characteristics and Trends of the Turkish Labour Market, 85-127, Ankara: Turkish Statistical Instutite.

Turkish Statistical Institute (2011). Income and Living Conditions Survey Micro Data Set (20062009).

Turkish Statistical Institute (2012). Press Release on the Household Labor Force Survey for January 2012.

World Bank (2010). Turkey Country Economic Memorandum (CEM) on Informality: Causes, Consequences, Policies, Washington D.C.: The World Bank.

Yamada, G. (1996). "Urban Informal Employment and Self-employment in Developing Countries: Theory and Evidence", Economic Development and Cultural Change, 44 (2), 289-314.

Yu, D. (2012). "Defining and measuring informal employment in South Africa: A review of recent approaches", Development Southern Africa, 29 (1), 157-17 
Table 1: Informality Rates by Gender

TOTAL SAMPLE

\begin{tabular}{|c|c|c|c|c|c|c|c|c|}
\hline & \multicolumn{4}{|c|}{ All Sample } & \multicolumn{4}{|c|}{$\underline{\text { Non-agricultural Sample }}$} \\
\hline & 2006 & 2007 & 2008 & 2009 & 2006 & 2007 & 2008 & 2009 \\
\hline Enterprise D. & 0.58 & 0.57 & 0.57 & 0.57 & 0.45 & 0.44 & 0.43 & 0.44 \\
\hline Social Sec. D. & 0.52 & 0.48 & 0.45 & 0.46 & 0.39 & 0.35 & 0.31 & 0.32 \\
\hline \multicolumn{9}{|c|}{ MALE SAMPLE } \\
\hline & \multicolumn{4}{|c|}{ All Sample } & \multicolumn{4}{|c|}{$\underline{\text { Non-agricultural Sample }}$} \\
\hline & 2006 & 2007 & 2008 & 2009 & 2006 & 2007 & 2008 & 2009 \\
\hline Enterprise D. & 0.54 & 0.53 & 0.53 & 0.54 & 0.46 & 0.45 & 0.45 & 0.44 \\
\hline Social Sec. D. & 0.45 & 0.42 & 0.37 & 0.40 & 0.38 & 0.35 & 0.30 & 0.32 \\
\hline \multicolumn{9}{|c|}{ FEMALE SAMPLE } \\
\hline & \multicolumn{4}{|c|}{$\underline{\text { All Sample }}$} & \multicolumn{4}{|c|}{$\underline{\text { Non-agricultural Sample }}$} \\
\hline & 2006 & 2007 & 2008 & 2009 & 2006 & 2007 & 2008 & 2009 \\
\hline Enterprise D. & 0.68 & 0.66 & 0.65 & 0.66 & 0.42 & 0.39 & 0.39 & 0.40 \\
\hline Social Sec. D. & 0.69 & 0.65 & 0.63 & 0.62 & 0.43 & 0.36 & 0.33 & 0.32 \\
\hline
\end{tabular}

Source : Author's own calculations based on SILC 2006-2009. 
Table 2: Informality Rates by Age

\begin{tabular}{|c|c|c|c|c|c|c|c|c|}
\hline & \multicolumn{4}{|c|}{ ALL SAMPLE } & \multicolumn{4}{|c|}{ NON-AGRICULTURAL SAMPLE } \\
\hline & 2006 & 2007 & 2008 & 2009 & 2006 & 2007 & 2008 & 2009 \\
\hline \multicolumn{9}{|l|}{ Age 15-24 } \\
\hline Enterprise D. & 0.60 & 0.59 & 0.59 & 0.61 & 0.50 & 0.48 & 0.48 & 0.49 \\
\hline Social Sec. D. & 0.67 & 0.61 & 0.55 & 0.60 & 0.57 & 0.50 & 0.42 & 0.46 \\
\hline \multicolumn{9}{|l|}{ Age 25-34 } \\
\hline Enterprise D. & 0.51 & 0.50 & 0.49 & 0.50 & 0.42 & 0.41 & 0.40 & 0.41 \\
\hline Social Sec. D. & 0.41 & 0.36 & 0.33 & 0.34 & 0.31 & 0.26 & 0.22 & 0.23 \\
\hline \multicolumn{9}{|l|}{ Age 35-44 } \\
\hline Enterprise D. & 0.56 & 0.54 & 0.54 & 0.53 & 0.44 & 0.42 & 0.42 & 0.42 \\
\hline Social Sec. D. & 0.43 & 0.40 & 0.37 & 0.37 & 0.31 & 0.28 & 0.25 & 0.25 \\
\hline \multicolumn{9}{|l|}{ Age 45-54 } \\
\hline Enterprise D. & 0.65 & 0.65 & 0.64 & 0.63 & 0.47 & 0.47 & 0.46 & 0.44 \\
\hline Social Sec. D. & 0.59 & 0.57 & 0.55 & 0.57 & 0.45 & 0.42 & 0.39 & 0.41 \\
\hline \multicolumn{9}{|l|}{ Age 55-64 } \\
\hline Enterprise D. & 0.82 & 0.80 & 0.81 & 0.82 & 0.59 & 0.56 & 0.60 & 0.56 \\
\hline Social Sec. D. & 0.85 & 0.82 & 0.80 & 0.81 & 0.73 & 0.71 & 0.67 & 0.65 \\
\hline
\end{tabular}




\begin{tabular}{|c|c|c|c|c|c|c|c|c|}
\hline & \multicolumn{4}{|c|}{ ALL SAMPLE } & \multicolumn{4}{|c|}{ NON-AGRICULTURAL SAMPLE } \\
\hline & 2006 & 2007 & 2008 & 2009 & 2006 & 2007 & 2008 & 2009 \\
\hline & \multicolumn{8}{|c|}{ Illiterate } \\
\hline Enterprise D. & 0.91 & 0.89 & 0.91 & 0.91 & 0.65 & 0.62 & 0.69 & 0.65 \\
\hline Social Sec. D. & 0.95 & 0.92 & 0.94 & 0.95 & 0.83 & 0.73 & 0.81 & 0.83 \\
\hline \multicolumn{9}{|l|}{ No Grade } \\
\hline Enterprise D. & 0.76 & 0.77 & 0.76 & 0.76 & 0.53 & 0.57 & 0.54 & 0.53 \\
\hline Social Sec. D. & 0.85 & 0.86 & 0.84 & 0.85 & 0.72 & 0.77 & 0.72 & 0.72 \\
\hline \multicolumn{9}{|l|}{ Primary } \\
\hline Enterprise D. & 0.70 & 0.68 & 0.68 & 0.70 & 0.55 & 0.53 & 0.54 & 0.55 \\
\hline Social Sec. D. & 0.58 & 0.59 & 0.54 & 0.58 & 0.44 & 0.45 & 0.40 & 0.44 \\
\hline \multicolumn{9}{|l|}{ Secondary } \\
\hline Enterprise D. & 0.62 & 0.58 & 0.58 & 0.62 & 0.53 & 0.49 & 0.49 & 0.53 \\
\hline Social Sec. D. & 0.53 & 0.52 & 0.48 & 0.53 & 0.43 & 0.44 & 0.39 & 0.43 \\
\hline \multicolumn{9}{|l|}{ High } \\
\hline Enterprise D. & 0.44 & 0.45 & 0.46 & 0.44 & 0.40 & 0.41 & 0.41 & 0.40 \\
\hline Social Sec. D. & 0.28 & 0.31 & 0.27 & 0.28 & 0.23 & 0.27 & 0.22 & 0.23 \\
\hline \multicolumn{9}{|l|}{ Vocational } \\
\hline Enterprise D. & 0.39 & 0.41 & 0.38 & 0.39 & 0.35 & 0.37 & 0.34 & 0.35 \\
\hline Social Sec. D. & 0.23 & 0.24 & 0.20 & 0.23 & 0.18 & 0.21 & 0.17 & 0.18 \\
\hline \multicolumn{9}{|l|}{ University } \\
\hline Enterprise D. & 0.22 & 0.24 & 0.21 & 0.22 & 0.21 & 0.23 & 0.20 & 0.21 \\
\hline Social Sec. D. & 0.09 & 0.11 & 0.08 & 0.09 & 0.07 & 0.10 & 0.07 & 0.07 \\
\hline
\end{tabular}




\begin{tabular}{|c|c|c|c|c|c|c|c|c|}
\hline & \multicolumn{4}{|c|}{ ALL SAMPLE } & \multicolumn{4}{|c|}{ NON-AGRICULTURAL SAMPLE } \\
\hline & 2006 & 2007 & 2008 & 2009 & 2006 & 2007 & 2008 & 2009 \\
\hline \multicolumn{9}{|l|}{ Regular employee } \\
\hline Enterprise D. & 0.32 & 0.32 & 0.30 & 0.31 & 0.31 & 0.31 & 0.30 & 0.31 \\
\hline Social Sec. D. & 0.26 & 0.22 & 0.17 & 0.18 & 0.26 & 0.21 & 0.17 & 0.18 \\
\hline \multicolumn{9}{|l|}{ Casual employee } \\
\hline Enterprise D. & 0.80 & 0.75 & 0.75 & 0.78 & 0.82 & 0.76 & 0.77 & 0.80 \\
\hline Social Sec. D. & 0.94 & 0.92 & 0.85 & 0.91 & 0.93 & 0.90 & 0.83 & 0.89 \\
\hline \multicolumn{9}{|l|}{ Employer } \\
\hline Enterprise D. & 0.88 & 0.87 & 0.88 & 0.87 & 0.88 & 0.87 & 0.88 & 0.87 \\
\hline Social Sec. D. & 0.38 & 0.30 & 0.25 & 0.27 & 0.35 & 0.26 & 0.22 & 0.23 \\
\hline \multicolumn{9}{|c|}{ Own-account worker } \\
\hline Enterprise D. & 0.79 & 0.77 & 0.78 & 0.78 & 0.56 & 0.54 & 0.56 & 0.57 \\
\hline Social Sec. D. & 0.72 & 0.68 & 0.64 & 0.68 & 0.62 & 0.57 & 0.53 & 0.58 \\
\hline \multicolumn{9}{|c|}{ Unpaid family worker } \\
\hline Enterprise D. & 0.99 & 0.99 & 0.99 & 0.99 & 0.91 & 0.94 & 0.95 & 0.95 \\
\hline Social Sec. D. & 0.94 & 0.93 & 0.93 & 0.95 & 0.81 & 0.79 & 0.77 & 0.82 \\
\hline
\end{tabular}


ALL SAMPLE

$\begin{array}{llll}2006 & 2007 & 2008 & 2009\end{array}$

Agriculture

$\begin{array}{lllll}\text { Enterprise D. } & 0.97 & 0.97 & 0.96 & 0.97\end{array}$

Social Sec. D. $\quad 0.90 \quad 0.89 \quad 0.87 \quad 0.89$

Mining

$\begin{array}{lllll}\text { Enterprise D. } & 0.16 & 0.20 & 0.19 & 0.21\end{array}$

Social Sec. D. $\quad 0.14 \quad 0.23 \quad 0.18 \quad 0.24$

Manufacturing

$\begin{array}{lllll}\text { Enterprise D. } & 0.33 & 0.32 & 0.33 & 0.33\end{array}$

Social Sec. D. $\quad 0.35 \quad 0.29 \quad 0.25 \quad 0.26$

Utilities

$\begin{array}{lllll}\text { Enterprise D. } & 0.03 & 0.04 & 0.07 & 0.06\end{array}$

$\begin{array}{lllll}\text { Social Sec. D. } \quad 0.01 & 0.01 & 0.02 & 0.04\end{array}$

Construction

$\begin{array}{lllll}\text { Enterprise D. } & 0.66 & 0.65 & 0.65 & 0.64\end{array}$

$\begin{array}{lllll}\text { Social Sec. D. } \quad 0.72 & 0.67 & 0.58 & 0.56\end{array}$

Trade

$\begin{array}{lllll}\text { Enterprise D. } & 0.64 & 0.63 & 0.61 & 0.61\end{array}$

$\begin{array}{lllll}\text { Social Sec. D. } & 0.47 & 0.43 & 0.35 & 0.37\end{array}$

Hotels\& Restaurants

$\begin{array}{lllll}\text { Enterprise D. } & 0.59 & 0.54 & 0.55 & 0.55\end{array}$

Social Sec. D. $\quad 0.48 \quad 0.45 \quad 0.44 \quad 0.45$

Source : Author's own calculations based on SILC 2006-2009.
ALL SAMPLE

$\begin{array}{llll}2006 & 2007 & 2008 & 2009\end{array}$

Transportation

$\begin{array}{lllll}\text { Enterprise D. } & 0.59 & 0.56 & 0.55 & 0.56\end{array}$

Social Sec. D. $\quad 0.49 \quad 0.43 \quad 0.38 \quad 0.43$

Finances

$\begin{array}{lllll}\text { Enterprise D. } & 0.22 & 0.21 & 0.22 & 0.20\end{array}$

Social Sec. D. $0.09 \quad 0.06 \quad 0.09 \quad 0.09$

Business services

$\begin{array}{lllll}\text { Enterprise D. } & 0.37 & 0.37 & 0.37 & 0.35\end{array}$

$\begin{array}{lllll}\text { Social Sec. D. } & 0.28 & 0.25 & 0.19 & 0.20\end{array}$

Public Administration

$\begin{array}{lllll}\text { Enterprise D. } & 0.08 & 0.11 & 0.10 & 0.11\end{array}$

Social Sec. D. $\quad 0.05 \quad 0.08 \quad 0.08 \quad 0.08$

Education

$\begin{array}{lllll}\text { Enterprise D. } & 0.07 & 0.09 & 0.07 & 0.10\end{array}$

Social Sec. D. $0.07 \quad 0.08 \quad 0.06 \quad 0.07$

Health

$\begin{array}{lllll}\text { Enterprise D. } & 0.15 & 0.15 & 0.12 & 0.12\end{array}$

Social Sec. D. $\quad 0.10 \quad 0.09 \quad 0.05 \quad 0.07$

Others

$\begin{array}{lllll}\text { Enterprise D. } & 0.78 & 0.74 & 0.74 & 0.78\end{array}$

$\begin{array}{lllll}\text { Social Sec. D. } & 0.64 & 0.55 & 0.56 & 0.62\end{array}$ 
Table 8: Probit Estimation Results Using Enterprise Definition

\begin{tabular}{|c|c|c|c|c|c|c|c|c|c|}
\hline & & \multicolumn{4}{|c|}{ ALL SAM PLE } & \multicolumn{4}{|c|}{ NON-AGRICULTURAL SAM PLE } \\
\hline & & 2006 & 2007 & 2008 & 2009 & 2006 & 2007 & 2008 & 2009 \\
\hline \multicolumn{10}{|c|}{ Gender } \\
\hline & female & 0.207 & 0.189 & 0.169 & $0.224 *$ & 0.168 & 0.189 & -0.169 & $-0.224 *$ \\
\hline \multicolumn{10}{|c|}{ Age } \\
\hline & age25to44 & $-0.334 *$ & -0.139 & $-0.315^{*}$ & $0.251 *$ & $-0.381 *$ & -0.139 & $0.315^{*}$ & $-0.251^{*}$ \\
\hline & age45to64 & $-0.520^{*}$ & -0.365 & $-0.523^{*}$ & 0.27 & $-0.542 *$ & -0.365 & $0.523 *$ & -0.27 \\
\hline \multicolumn{10}{|c|}{ Schooling } \\
\hline & illiterate & -0.342 & -0.742 & -0.131 & $-0.366^{*}$ & -0.871 & -0.742 & 0.131 & $0.366^{*}$ \\
\hline & noschool & -0.5 & -0.252 & $-0.565^{*}$ & -0.177 & -0.523 & -0.252 & $0.565 *$ & 0.177 \\
\hline & secondary & $0.505 * * *$ & $0.328 * *$ & 0.0722 & 0.14 & $0.540 * * *$ & $0.328^{* *}$ & -0.0722 & -0.14 \\
\hline & high & $0.457 * * *$ & $0.414 * * *$ & $0.282 *$ & $0.290 * *$ & $0.492 * * *$ & $0.414 * * *$ & $-0.282 *$ & $-0.290 * *$ \\
\hline & vocational & $0.671 * * *$ & $0.727 * * *$ & $0.380 * *$ & $0.256^{*}$ & $0.689 * * *$ & $0.727 * * *$ & $-0.380 * *$ & $-0.256^{*}$ \\
\hline & university & $0.771 * * *$ & $0.919 * * *$ & $0.427 * *$ & $0.450 * * *$ & $0.792 * * *$ & $0.919 * * *$ & $-0.427 * *$ & $-0.450 * * *$ \\
\hline \multicolumn{10}{|c|}{ Household type } \\
\hline & married & 0.0905 & 5.967 & 0.135 & $1.905 * * *$ & 0.0845 & 5.967 & -0.135 & $-1.905 * * *$ \\
\hline & hhead & 0.093 & 0.107 & 0.117 & 0.125 & 0.162 & 0.107 & -0.117 & -0.125 \\
\hline & child & -0.0131 & 0.00327 & $-0.201 *$ & 0.0456 & -0.0123 & 0.00327 & $0.201 *$ & -0.0456 \\
\hline \multicolumn{10}{|c|}{ Experience } \\
\hline & exper & 0.0192 & 0.000137 & -0.0225 & -0.0842 & 0.0125 & 0.000137 & 0.0225 & 0.0842 \\
\hline & exper sq & -0.000316 & -0.0035 & 0.000457 & -0.0187 & -0.000177 & -0.0035 & -0.000457 & 0.0187 \\
\hline \multicolumn{10}{|c|}{ Sector } \\
\hline & Agriculture & 0.57 & 0.000137 & 0.369 & 0.000395 & & 0.000137 & -0.369 & -0.000395 \\
\hline & Mining & -3.464 & 0.466 & -0.253 & $0.737 * *$ & -3.5 & 0.466 & 0.253 & $-0.737 * *$ \\
\hline & Energy & -0.653 & 0.49 & 0.336 & -0.793 & -0.239 & 0.49 & -0.336 & 0.793 \\
\hline & Construction & -0.513 & 0.475 & 0.0546 & $0.661 *$ & -0.507 & 0.475 & -0.0546 & $-0.661 *$ \\
\hline & Trade & $-1.406^{* * * *}$ & 0.0109 & $-0.980 * * *$ & -0.0769 & $-1.393 * * *$ & 0.0109 & $0.980^{* * *}$ & 0.0769 \\
\hline & Hotels & $-0.704 * *$ & $-1.080^{* * * *}$ & $-0.469 * *$ & $-0.348^{* *}$ & $-0.660 * *$ & $-1.080^{* * * *}$ & $0.469 * *$ & $0.348 * *$ \\
\hline & Transportation & 0.161 & -0.217 & -0.18 & -0.129 & 0.174 & -0.217 & 0.18 & 0.129 \\
\hline & Finances & $-1.690^{* * * *}$ & $-0.473 *$ & $-1.242 * * *$ & -0.229 & $-1.702 * * *$ & $-0.473 *$ & $1.242 * * *$ & 0.229 \\
\hline & PublicAdministral & 0.341 & $-1.282 * * *$ & $1.142 * * *$ & $-0.477 * *$ & $0.600 * *$ & $-1.282 * * *$ & $-1.142 * * *$ & $0.477 * *$ \\
\hline & Education & 0.111 & $1.023 * * *$ & -0.375 & $0.488 *$ & 0.0961 & $1.023 * * *$ & 0.375 & $-0.488^{*}$ \\
\hline & Health & $-1.166^{* * * *}$ & -0.0368 & $-1.087 * * *$ & -0.041 & $-1.139 * *$ & -0.0368 & $1.087 * * *$ & 0.041 \\
\hline & OtherServices & $-0.881 * * *$ & $-1.013 * *$ & $-0.774 * * *$ & $-0.578^{*}$ & $-0.848 * * *$ & $-1.013 * *$ & $0.774 * * *$ & $0.578^{*}$ \\
\hline \multicolumn{10}{|c|}{ Occupation } \\
\hline & Legislators & $-0.647 * * *$ & $-0.654 * *$ & $-0.858 * * *$ & 0.179 & $-0.668 * * *$ & $-0.654 * *$ & $0.858 * * *$ & -0.179 \\
\hline & Technicians & $0.346^{*}$ & $-0.538 * * *$ & -0.0291 & $-0.579 * * *$ & 0.345 & $-0.538 * * *$ & 0.0291 & $0.579 * * *$ \\
\hline & Clerks & $11.60 * * *$ & $0.396^{*}$ & $11.78^{* * *}$ & 0.171 & $12.62 * * *$ & $0.396^{*}$ & $-11.78 * * *$ & -0.171 \\
\hline & ServiceWorkers & 6.932 & $11.81 * * *$ & $6.936^{* * *}$ & $1.726 * * *$ & 7.581 & $11.81 * * *$ & $-6.936 * * *$ & $-1.726 * * *$ \\
\hline & SkilledAgricultur: & $13.72 * * *$ & $7.183 * * *$ & 14.26 & $1.736^{* * *}$ & 6.574 & $7.183 * * *$ & -14.26 & $-1.736^{* * * *}$ \\
\hline & Craftsmen & $11.54 * * *$ & 14.69 & $12.25 * * *$ & $3.625 * * *$ & $12.54 * * *$ & 14.69 & $-12.25 * * *$ & $-3.625 * * *$ \\
\hline & PlantOperators & $11.43^{* * * *}$ & $12.17 * * *$ & $11.90 * * *$ & $1.967 * * *$ & 12.43 & $12.17 * * *$ & $-11.90 * * *$ & $-1.967 * * *$ \\
\hline & ElementaryOpera & $11.56^{* * * *}$ & $12.44 * * *$ & $11.75 * * *$ & $1.825 * * *$ & $12.84 * * *$ & $12.44 * * *$ & $-11.75 * * *$ & $-1.825 * * *$ \\
\hline \multicolumn{10}{|c|}{ Firm size } \\
\hline & medium & $-15.66^{* * * *}$ & $12.42 * * *$ & $-16.20 * * *$ & $1.423 * * *$ & $-16.64 * * *$ & $12.42 * * *$ & $16.20 * * *$ & $-1.423 * * *$ \\
\hline & large & -16.66 & $-16.17 * * *$ & & $-4.900 * * *$ & & $-16.17 * * *$ & & $4.900 * * *$ \\
\hline \multicolumn{10}{|c|}{ Region } \\
\hline & urban & $0.353 * * *$ & $0.327 * * *$ & $0.376^{* * *}$ & 0.0983 & $0.423 * * *$ & $0.327 * * *$ & $-0.376 * * *$ & -0.0983 \\
\hline $\mathbf{N}$ & & 13016 & 11008 & 11338 & 11752 & 6128 & 11008 & 11338 & 11752 \\
\hline
\end{tabular}

Author's own calculations based on SILC 2006-2009.

Notes : ${ }^{1}$ For variable definitions, see Appendix Table A.1. ${ }^{2}$ The results are marginal effects for the Probit Model. ${ }^{3}$ Dependent variable base category: Formal based on definition A. ${ }^{4}$ Independent variable base category: Male, age 15-24, primary school graduate, single, not household head, does not have children, manufacturing sector, professional occupation, small size firms, rural.

Legend: * for $\mathrm{p}<.05, * *$ for $\mathrm{p}<.01$, and $* * *$ for $\mathrm{p}<.001$ 
Table 10: Probit Estimation Results Using Social Security Definition

\begin{tabular}{|c|c|c|c|c|c|c|c|c|c|}
\hline & \multicolumn{4}{|c|}{ ALL SAM PLE } & \multicolumn{4}{|c|}{ NON-AGRICULTURAL SAMPLE } \\
\hline & & 2006 & 2007 & 2008 & 2009 & 2006 & 2007 & 2008 & 2009 \\
\hline & \multicolumn{9}{|c|}{ Gender } \\
\hline & female & $0.452 * * *$ & $0.395 * * *$ & $0.529 * * *$ & $0.433 * * *$ & $0.187 * * *$ & $0.395 * * *$ & $0.529 * * *$ & $0.433 * * *$ \\
\hline \multicolumn{10}{|c|}{ Age } \\
\hline & age25to44 & $-0.408 * * *$ & $-0.389 * * *$ & $-0.299 * * *$ & $-0.332 * * *$ & $-0.361 * * *$ & $-0.389 * * *$ & $-0.299 * * *$ & $-0.332 * * *$ \\
\hline & age45to64 & -0.0365 & -0.0737 & 0.0716 & 0.0941 & 0.0873 & -0.0737 & 0.0716 & 0.0941 \\
\hline \multicolumn{10}{|c|}{ Schooling } \\
\hline & illiterate & $0.620 * * *$ & $0.475^{* * *}$ & $0.640 * * *$ & $0.551 * * *$ & $0.525 * * *$ & $0.475 * * *$ & $0.640 * * *$ & $0.551 * * *$ \\
\hline & noschool & $0.496^{* * *}$ & $0.422 * * *$ & $0.476^{* * *}$ & $0.575^{* * *}$ & $0.482 * * *$ & $0.422 * * *$ & $0.476^{* * *}$ & $0.575^{* * *}$ \\
\hline & secondary & $-0.135^{* *}$ & $-0.0865^{*}$ & -0.0573 & -0.0736 & $-0.162 * *$ & $-0.0865^{*}$ & -0.0573 & -0.0736 \\
\hline & high & $-0.384 * * *$ & $-0.342 * * *$ & $-0.342^{* * * *}$ & $-0.376 * * *$ & $-0.402 * * *$ & $-0.342 * * *$ & $-0.342 * * *$ & $-0.376^{* * * *}$ \\
\hline & vocational & $-0.520^{* * * *}$ & $-0.466 * * *$ & $-0.442 * * *$ & $-0.445 * * *$ & $-0.565^{* * *}$ & $-0.466^{* * * *}$ & $-0.442 * * *$ & $-0.445^{* * *}$ \\
\hline & university & $-0.444 * * *$ & $-0.467 * * *$ & $-0.534 * * *$ & $-0.639 * * *$ & $-0.455^{* * *}$ & $-0.467 * * *$ & $-0.534 * * *$ & $-0.639 * * *$ \\
\hline \multicolumn{10}{|c|}{ Household type } \\
\hline & married & $-0.212 * * *$ & $-0.194 * * *$ & $-0.271 * * *$ & $-0.248 * * * *$ & $-0.224 * * *$ & $-0.194 * * *$ & $-0.271 * * *$ & $-0.248 * * *$ \\
\hline & hhead & $-0.194 * * *$ & $-0.195 * * *$ & $-0.160 * * *$ & $-0.194 * * *$ & -0.0999 & $-0.195 * * *$ & $-0.160 * * *$ & $-0.194 * * *$ \\
\hline & child & $0.0842 *$ & $0.164 * * *$ & $0.188^{* * *}$ & $0.107 * *$ & 0.0325 & $0.164 * * *$ & $0.188 * * *$ & $0.107 * *$ \\
\hline \multicolumn{10}{|c|}{ Experience } \\
\hline & exper & $-0.0204 * * *$ & -0.00741 & $-0.0154 * *$ & $-0.0166^{* *}$ & $-0.0413^{* * *}$ & -0.00741 & $-0.0154 * *$ & $-0.0166^{* *}$ \\
\hline & expersq & $0.000488^{* * *}$ & $0.000277 *$ & $0.000472^{* * *}$ & $0.000491 * * *$ & $0.00107^{* * *}$ & $0.000277^{*}$ & $0.000472 * * *$ & $0.000491 * * *$ \\
\hline \multicolumn{10}{|c|}{ Sector } \\
\hline & Agriculture & $1.194 * * *$ & $1.341 * * *$ & $0.976^{* * * *}$ & $1.254 * * *$ & & $1.341 * * *$ & $0.976^{* * *}$ & $1.254 * * *$ \\
\hline & Mining & -0.236 & 0.22 & 0.177 & $0.467 * *$ & -0.261 & 0.22 & 0.177 & $0.467 * *$ \\
\hline & Energy & $-0.794 *$ & -0.734 & -0.775 & -0.366 & $-0.889 * *$ & -0.734 & -0.775 & -0.366 \\
\hline & Construction & $0.753^{* * *}$ & $0.832 * * *$ & $0.727 * * *$ & $0.665^{* * *}$ & $0.706 * * *$ & $0.832 * * *$ & $0.727 * * *$ & $0.665^{* * *}$ \\
\hline & Trade & -0.0168 & $0.119^{*}$ & 0.0619 & 0.077 & -0.0513 & $0.119^{*}$ & 0.0619 & 0.077 \\
\hline & Hotels & 0.0839 & $0.310^{* * *}$ & $0.341 * * *$ & $0.418^{* * *}$ & 0.0495 & $0.310^{* * *}$ & $0.341 * * *$ & $0.418^{* * *}$ \\
\hline & Transportation & $0.338 * * *$ & $0.462 * * *$ & $0.500 * * *$ & $0.494 * * *$ & $0.270 * * *$ & $0.462 * * * *$ & $0.500 * * *$ & $0.494 * * *$ \\
\hline & Finances & -0.0903 & 0.0387 & -0.0517 & 0.0394 & -0.121 & 0.0387 & -0.0517 & 0.0394 \\
\hline & PublicAdmin. & $-0.478^{* * * *}$ & -0.0123 & 0.0913 & 0.0583 & $-0.554 * * *$ & -0.0123 & 0.0913 & 0.0583 \\
\hline & Education & $-0.366^{* *}$ & -0.107 & -0.189 & $-0.247^{*}$ & $-0.326^{*}$ & -0.107 & -0.189 & $-0.247^{*}$ \\
\hline & Health & $-0.571^{* * *}$ & -0.193 & $-0.537 * * *$ & $-0.402 * *$ & $-0.485^{* * *}$ & -0.193 & $-0.537 * * *$ & $-0.402^{* *}$ \\
\hline & OtherServices & $0.286^{* * *}$ & $0.331 * * *$ & $0.448^{* * *}$ & $0.602 * * *$ & $0.258^{* *}$ & $0.331 * * *$ & $0.448^{* * * *}$ & $0.602 * * *$ \\
\hline \multicolumn{10}{|c|}{ Occupation } \\
\hline & Legislators & $0.308^{* *}$ & $0.462 * * *$ & $0.474 * * *$ & $0.510 * * *$ & $0.252 *$ & $0.462 * * *$ & $0.474 * * *$ & $0.510^{* * * *}$ \\
\hline & Technicians & 0.218 & $0.275^{*}$ & $0.399 * * *$ & $0.349 * *$ & $0.238 *$ & $0.275^{*}$ & $0.399 * * *$ & $0.349 * *$ \\
\hline & Clerks & 0.0435 & 0.0734 & -0.0183 & 0.151 & 0.149 & 0.0734 & -0.0183 & 0.151 \\
\hline & ServiceWork & $0.601 * * *$ & $0.757 * * *$ & $0.651 * * *$ & $0.718 * * *$ & $0.627 * * *$ & $0.757 * * *$ & $0.651^{* * *}$ & $0.718^{* * *}$ \\
\hline & SkilledAgricul. & 0.0353 & 0.159 & $0.481 * * *$ & $0.293 *$ & 0.389 & 0.159 & $0.481 * * *$ & $0.293 *$ \\
\hline & Craftsmen & $0.687 * * *$ & $0.847 * * *$ & $0.768^{* * *}$ & $0.876^{* * *}$ & $0.673 * * *$ & $0.847 * * *$ & $0.768 * * *$ & $0.876^{* * *}$ \\
\hline & PlantOperator & $0.553^{* * *}$ & $0.597 * * *$ & $0.523 * * *$ & $0.676^{* * *}$ & $0.556 * * *$ & $0.597 * * *$ & $0.523 * * *$ & $0.676^{* * *}$ \\
\hline & ElementaryOp & $0.678 * * *$ & $0.832 * * *$ & $0.893^{* * *}$ & $0.874 * * *$ & $0.661 * * *$ & $0.832 * * *$ & $0.893 * * *$ & $0.874 * * *$ \\
\hline \multicolumn{10}{|c|}{ Firm size } \\
\hline & medium & $-0.799 * * *$ & $-0.705^{* * * *}$ & $-0.751 * * *$ & $-0.770 * * *$ & $-0.802^{* * * *}$ & $-0.705 * * *$ & $-0.751 * * *$ & $-0.770^{* * *} *$ \\
\hline & large & $-1.548^{* * *}$ & $-1.457 * * *$ & $-1.405 * * *$ & $-1.555 * * *$ & $-1.528 * * *$ & -1.457 **** & $-1.405^{* * *}$ & $-1.555^{* * *}$ \\
\hline \multicolumn{10}{|c|}{ Region } \\
\hline & urban & -0.0465 & -0.0641 & $-0.110^{* * *}$ & $-0.157 * * *$ & 0.0142 & -0.0641 & $-0.110 * * *$ & $-0.157 * * *$ \\
\hline$N$ & & 13016 & 13457 & 13950 & 14368 & 8412 & 13457 & 13950 & 14368 \\
\hline
\end{tabular}

Author's own calculations based on SILC 2006-2009.

Notes : ${ }^{1}$ For variable definitions, see Appendix Table A.1. ${ }^{2}$ The results are marginal effects for the Probit Model. ${ }^{3}$ Dependent variable base category: Formal based on Social Sec. D.. ${ }^{4}$ Independent variable base category: Male, age 15-24, primary school graduate, single, not household head, does not have children, manufacturing sector, professional occupation, small size firms, rural. .

Legend: * for $\mathrm{p}<.05, * *$ for $\mathrm{p}<.01$, and $* * *$ for $\mathrm{p}<.001$ 


\begin{tabular}{|c|c|}
\hline Variable Name & Definition \\
\hline \multicolumn{2}{|l|}{ Definition A } \\
\hline Formal & 1 if employee or employer in a firm with more than 10 workers or an administrative, professional or technician \\
\hline Informal & $\begin{array}{l}1 \text { if employee or employer in a firm with less than } 10 \text { workers or own account-worker (excluding administrative, } \\
\text { professional and technicians) or unpaid family workers; } 0 \text { otherwise }\end{array}$ \\
\hline \multicolumn{2}{|r|}{ 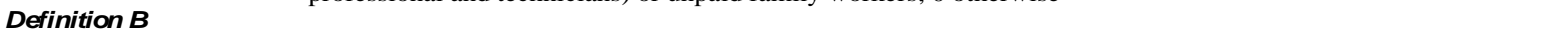 } \\
\hline Formal & $\begin{array}{l}1 \text { if employee or employer in a firm with more than } 10 \text { workers or an administrative, professional or technician } \\
\text { and who are registered to the social security institute; } 0 \text { otherwise }\end{array}$ \\
\hline Informal & $\begin{array}{l}1 \text { if employee or employer in a firm with less than } 10 \text { workers or own account-worker (excluding administrative, } \\
\text { professional and technicians) or unpaid family workers and those who are categorized as formal in Definition A } \\
\text { but is not registered to SSI; } 0 \text { otherwise }\end{array}$ \\
\hline \multicolumn{2}{|r|}{ (2) } \\
\hline Formal & 1 if registered to the social security institute for main job; 0 otherwise. \\
\hline Informal & 1 if not registered to the social security institute for main job; 0 otherwise. \\
\hline \multicolumn{2}{|c|}{ Individual Characteristics } \\
\hline male & 1 if male; 0 otherwise \\
\hline female & 1 if female; 0 otherwise \\
\hline age 15 to 24 & 1 if in age range; 0 otherwise \\
\hline age 25 to 44 & 1 if in age range; 0 otherwise \\
\hline age45to64 & 1 if in age range; 0 otherwise \\
\hline iIlliterate & 1 if illiterate; 0 otherwise \\
\hline noschool & 1 if did not attend school; 0 otherwise \\
\hline primary & 1 if completed primary school; 0 otherwise \\
\hline secondary & 1 if completed secondary school; 0 otherwise \\
\hline high & 1 if completed high school; 0 otherwise \\
\hline vocational & 1 if completed vocational school; 0 otherwise \\
\hline university & 1 if completed university; 0 otherwise \\
\hline \multicolumn{2}{|c|}{ Household Characteristics } \\
\hline single & 1 if not married; 0 otherwise \\
\hline married & 1 if married; 0 otherwise \\
\hline nochild & 1 if the household do not have any children; 0 otherwise \\
\hline child & 1 if the household has children; 0 otherwise \\
\hline hhead & 1 if head of the household; 0 otherwise \\
\hline \multicolumn{2}{|c|}{ Employment/Job Characteristics } \\
\hline $\begin{array}{l}\text { exper } \\
\text { expersq }\end{array}$ & $\begin{array}{l}\text { total number of years the individual has worked for since he/she first started working } \\
\text { experince squared }\end{array}$ \\
\hline Agriculture & 1 if employed in agriculture; 0 otherwise \\
\hline Mining & 1 if employed in mining; 0 otherwise \\
\hline Manufacturing & 1 if employed in manufacturing; 0 otherwise \\
\hline Energy & 1 if employed in energy; 0 otherwise \\
\hline Construction & 1 if employed in construction; 0 otherwise \\
\hline Trade & 1 if employed in trade; 0 otherwise \\
\hline Hotels & 1 if employed in hotels; 0 otherwise \\
\hline Transportation & 1 if employed in transportation; 0 otherwise \\
\hline Finances & 1 if employed in finances; 0 otherwise \\
\hline Public Administration & 1 if employed in piblic administration; 0 otherwise \\
\hline Education & 1 if employed in education; 0 otherwise \\
\hline Health & 1 if employed in health; 0 otherwise \\
\hline Other & 1 if employed in other services; 0 otherwise \\
\hline Legislators & 1 if employed as a legislator; 0 otherwise \\
\hline Professional & 1 if employed as a professional; 0 otherwise \\
\hline Technicals & 1 if employed as a technician; 0 otherwise \\
\hline Clerks & 1 if employed as a clerk; 0 otherwise \\
\hline Service workers & 1 if employed as a service worker; 0 otherwise \\
\hline \multicolumn{2}{|c|}{ Skilled agricultural worke 1 if employed as a skilled agricultural worker; 0 otherwise } \\
\hline Craftsmen & 1 if employed as a craftsmen; 0 otherwise \\
\hline Plant operators & 1 if employed as a plant operator; 0 otherwise \\
\hline Elementary operations & 1 if employed as a elemenatry opr. worker; 0 otherwise \\
\hline small & 1 if firm size is between 1 to 10 ; 0 otherwise \\
\hline medium & 1 if firm size is between 11 to 49 ; 0 otherwise \\
\hline large & 1 if firm size is 50 or more; 0 otherwise \\
\hline urban & 1 if individual resides in an urban area; 0 otherwise \\
\hline rural & 1 if individual resides in an rural area; 0 otherwise \\
\hline
\end{tabular}

